\title{
Functional response of Coccinella septempunctata L. (Coleoptera: Coccinellidae) on Ommatissus lybicus (Homoptera: Tropiduchidae)
}

\author{
Arif Shah ${ }^{1 *}$, Muhammad Qasim Kakar², Atta Ullah'², Abdul Razaq², \\ Nikos E. Papanikolaou ${ }^{3}$, Toheed Iqbal ${ }^{4}$ and Habib Ullah ${ }^{5}$ \\ 1. Balochistan Agriculture College Quetta, Pakistan \\ 2. Department of Agriculture (Extension) Balochistan, Pakistan \\ 3. Biodiversity Conservation Laboratory, Department of Environmental Sciences, University of the Aegeen, \\ Mytilene 81100, Greece. \\ 4. Department of Entomology, University of Agriculture, Peshawar, Pakistan \\ 5. Department of Agriculture (Research) Balochistan, Pakistan \\ *Corresponding author's email: arifshahkakar@gmail.com \\ Citation \\ Arif Shah, Muhammad Qasim Kakar, Atta Ullah, Abdul Razaq, Nikos E. Papanikolaou, Toheed Iqbal, and \\ Habib Ullah. Functional response of Coccinella septempunctata L. (Coleoptera: Coccinellidae) on Ommatissus \\ lybicus (Homoptera: Tropiduchidae). Pure and Applied Biology. Vol. 5, Issue 4, pp671-681. \\ http://dx.doi.org/10.19045/bspab.2016.50069
}

\begin{tabular}{llll}
\hline \hline Received: 26/05/2016 & Revised: 02/06/2016 & Accepted: 10/06/2016 & Online First: 17/06/2016 \\
\hline \hline
\end{tabular}

\section{Abstract}

Dubas bug, Ommatissus lybicus (Homoptera: Tropiduchidae), is a major insect pest of date palm. Adult and nymph stages suck sap from all green parts and cause direct and indirect damage. Large number of predators feed on it; however, no information is available on their consumption rate and functional response using this prey. We aim to find out consumption rate of Coccinella septempunctata with an objective how adult female and fourth nymphal instars of $C$. septempunctata responds to $1^{\text {st }}$ and $3^{\text {rd }}$ instar nymphs of $O$. lybicus at various density levels under controlled condition. Both stages of $C$. septempunctata exhibited a type II functional response. Handling times and attack rates were significantly different between adult female and larval stage indicating that predator responds differentially to prey stage offered at same density. Estimated handling time of $C$. septempunctata adult female and fourth instar (in bracket) at 24 hours were 0.563(0.692) and 1.008(1.492) and estimated attack rate were $0.020(0.014)$ and $0.003(0.002)$ on first and third instar nymphs of prey, respectively, which conclude that adult is more voracious stage than larva. However, further field studies on predator and prey stage specific in the presence of honeydew droplets on leaflets are still needed to quantify biocontrol efficiency of predator.

Keywords: Bivoltine; Coccinella septempunctata; Dubas bug; Honeydew; Predation

\section{Introduction}

Dubas bug, Ommatissus lybicusis (Homoptera: Tropiduchidae), an important sucking pest of date palm on the Arab peninsula [1]. This monophagous and bivoltine pest is recorded in several countries in the near East and North Africa
[2-5]. In Pakistan, it was first recorded in 1999 in district Panjgur of Balochistan [6]. Adult and nymph stages of $O$. lybicus suck the phloem sap from all green parts of date palm and cause direct and indirect damage by puncturing the tissue and secretion of honeydew droplets on leaflets which 
results in poor photosynthetic activity [1, 7] and may cause yield losses up to $50 \%$ in Iraq [8]. In Pakistan yield losses ranged from $35-80 \%$ but susceptible cultivars may fail to produce [6].

Coccinellids, commonly known as ladybirds, feed on a large number of prey and have been getting importance as biocontrol agents [9-11]. Adults and larvae of most species of coccinellids are the potential predators of a variety of prey [11]. Coccinella septempunctata L., is one of the potential predators of aphids in India [12].

The functional response of predator is a key factor in the population dynamics of predator-prey systems. It illustrated the rate at which a predator kills its prey at different levels of density [13]. The effectiveness of the predators is directly related to the type of functional response $[14,15]$ and such information is critical for implementing natural enemies conservation and augmentation of natural biological control program [16]. Type of functional response is of immense practical importance in estimating the bioefficacy of predatory insect, however ecologists usually face difficulties in determining functional response when the curve lies between Type II and III. Hence suitable analysis that can best determine the functional response is intensely required [17].

In Panjgur, coccinellids spp., Chrysopa spp., black ants sp. and spider spp. are commonly found predators in date palm agro-ecosystem where these predators were observed to feed on nymphs and adult stages of dubas bug [6].

Adults of coccinellids, C. septempunctata, C. undecimpunctata L., Chilocorus bipustulatus L. and larvae of Chrysoperla carnea Steph. feed upon the nymphs and adults stages of $O$. lybicus $[3,4,18]$. However, no information is available on consumption rate and functional response of any predator who is attacking this pest. The aim of this study was to test the consumption rate and evaluate the functional response of $C$. septempunctata raising the following questions (i) Does the predation rate of adult female and $4^{\text {th }}$ instar larval stages of $C$. septempunctata vary when fed on same density of same or different prey stages? (ii) Do the functional response curves of adult and larva vary when fed on same prey stage?

\section{Materials and methods}

The study was conducted for the four consecutive generations in spring and summer 2009-10, in district Panjgur $\left(26{ }^{\circ} 59.165^{\circ} \mathrm{N} 064{ }^{\circ} 05.880^{\circ} \mathrm{E}\right.$ Alt. $\left.3200 \mathrm{ft}\right)$ of Balochistan.

\section{Predator's selection and identification}

In order to select the most efficient predator a preliminary study on consumption rate of $C$. septempunctata, on different life forms of dubas bug was carried out in Petri dishes (experiment arena) in summer generation $\left(2^{\text {nd }}\right)$ in the year 2008. Based on comparatively high consumption rate $C$. septempunctata was selected for the present study.

\section{Frond and cage size selection}

Number of fully expanded fronds of Kehraba cultivar with ten (10) middle leaflets; five on each side were selected. Both cut ends (sides) of frond were covered with wet cotton to reduce water losses and keep the turgidity of leaflets during the course of experiment. A single frond was placed in each cages $(20 \times 17 \times 3$ inch) with a wooden frame and covered by muslin cloth in order to maintain the prey and predator similar to natural/field conditions.

\section{Prey stage selection and culture}

Two developmental stages $\left(1^{\text {st }}\right.$ and $3^{\text {rd }}$ instar nymphs) of dubas bug (prey) were chosen. In order to test the predation rate and determine the functional response of both stages of predator on each developmental stage of prey at a time, a number of $1^{\text {st }}$ instar nymphs of dubas bug were collected with aspirator and maintained as stock population. When more than $90 \%$ of the stock population of prey reached to $3^{\text {rd }}$ instar, required numbers of $1^{\text {st }}$ instar nymphs were 
collected from field and offered to the predator. Similarly, stock population of $C$. septempunctata was maintained on Medicago sativa and fed with aphids.

\section{Estimating consumption rate and} functional response

Consumption rate and functional response of fourth instar and adult female of $C$. septempunctata were determined by offering the $1^{\text {st }}$ and $3^{\text {rd }}$ instar nymphs of dubas bug at different density levels $(1,5$, $10,20,40$, and 60 bugs per leaflet or a total of 10, 50, 100, 200, 400 and 600 bugs per cage). Each life stage of predator and density level of prey was released randomly into the single cage to each predator stage. Similarly, control cages received corresponding prey density level and developmental stages but no predator. Both stages of predators were starved for 24 hours before introducing into the cages. Exposure time of prey to predator was 24 hours and without replacement of prey. Following 24 hours, mean number of killed/consumed prey were counted in both treated and control cages. The experiment was conducted controlled conditions (temperature $30 \pm 2{ }^{\circ} \mathrm{C}$, R.H. $20 \pm 2 \%$ and photoperiod 16L:8D) replicated five times.

\section{Data analysis}

The logistic regression model [19] was used to determine the shape of the functional response prior to fitting the data for functional response analysis. This model helps distinguishing between Type II and Type III [17]. The relationship between the proportion of prey consumed $\left(\mathrm{N}_{\mathrm{e}} / \mathrm{N}_{0}\right)$ and number of prey present $\left(\mathrm{N}_{0}\right)$ was determined by fitting the data to a polynomial function (equation 1) using statistical software SAS, Version 9.0 (Procedure CATMOD) on personal computer.

$$
N_{e} / N_{0}=\frac{\exp \left(P_{0}+P_{1} N_{0}+P_{2} N_{0}^{2}+P_{3} N_{0}^{3}\right)}{1+\exp \left(P_{0}+P_{1} N_{0}+P_{2} N_{0}^{2}+P_{3} N_{0}^{3}\right)}(1)
$$

Where $\mathrm{P}_{\mathrm{o}}, \mathrm{P}_{1}, \mathrm{P}_{2}$, and $\mathrm{P}_{3}$ were the intercept, linear, quadratic and cubic coefficients, respectively, which were estimated using maximum likelihood method. If $\mathrm{P}_{1}>0$ and
$\mathrm{P}_{2}<0$, the proportion of prey consumed is positively density dependent, thus describing a type III functional response. If $\mathrm{P}_{1}<0$, the proportion of prey consumed declines with initial prey density suggesting a type II functional response [19]. Later on, the functional response parameters were estimated using Roger's random predator equation (Rogers 1972). For Type II response the equation will be followed:

$$
N_{e}=N_{0}\left\{1-\exp \left[a\left(T_{h} N_{e}-T\right)\right]\right\}
$$

Where, $\mathrm{N}_{\mathrm{e}}$ is number of prey consumed and $\mathrm{N}_{0}$ is initial prey density, $a$ is the attack rate, $\mathrm{T}$ is the total time of exposure, and $\mathrm{T}_{\mathrm{h}}$ is the handling time. Random predator equation overcomes the problem of prey depletion. Data fitting was performed using nonlinear least square method on SAS Version 9.0 (Procedure NLIN) [19].

For Type III response equation will be followed:

$\mathrm{N}_{\mathrm{e}}=\mathrm{N}_{\mathrm{o}}\left\{1-\exp \left[\left(\mathrm{d}+\mathrm{b} \mathrm{N}_{\mathrm{o}}\right)\left(\left(\mathrm{T}_{\mathrm{h}} \mathrm{N}_{\mathrm{e}} \mathrm{T}\right) /\left(1+\mathrm{cN}_{\mathrm{o}}\right)\right]\right\}\right.$

where $b, c$ and $d$ are constants.

The data on prey consumption by fourth instar and adult female $C$. septempunctata at different prey stage level were subjected to one-way ANOVA and the comparison of means was done using Tukey's HSD test using statistical software, SAS. The number of first and third instar nymphs of dubas bug at different density levels consumed by fourth instar and adult female of $C$. septempunctata in 24 hours were analyzed using two-way ANOVA by using "prey stage" and "prey density" level as independent factor and "prey consumed" as dependent factor using statistical software, SAS.

\section{Results}

Consumption Rate (average of four seasons) C. septempunctata (adult female) vs. Dubas bug first and third instar nymph

Consumption rate of adult female $C$. septempunctata fed on first $(\mathrm{F}=162.98$; $\mathrm{P}<0.0001 ;$ d.f. $=5,29)$ and third $(\mathrm{F}=121.19 ; \mathrm{P}<0.0001$; d.f. $=5$, 29; Table1) instars of dubas bug increased significantly with increase in prey density 
levels. Comparison of means revealed that prey consumption was significant at all the density levels except at prey densities, 400 and 600 of first instar nymph when adult female was used as predator (Tukey's range $=4.31$ ).

C. septempunctata (grub) vs. Dubas bug first and third instar nymph

Almost similar trend was observed when fourth instar $C$. septempunctata was used as predator at different densities of first and third instars of dubas bug (table 2 and figure. 1). Prey consumption by fourth instar of $C$. septempunctata increased significantly with increase in densities of first $(\mathrm{F}=205.82 ; \mathrm{P}<0.0001 ;$ d.f. $=5,29)$ and third $(\mathrm{F}=121.93 ; \mathrm{P}<0.0001 ;$ d.f. $=5$, 29) instar nymphs of dubas bug. Mean values also varied significantly at all the density levels except at prey densities, 400 and 600 of first instar nymph when fourth instar C. septempunctata was used as predator (Tukey's range $=4.31$ ).

Table 1. Mean number $( \pm \mathrm{SE})$ of first and third instar nymphs of $O$. lybicus, consumed (in 24 hours) by adult female $C$. septempunctata at different prey densities (average of four seasons: spring and summer, 2009-10)

\begin{tabular}{|c|c|c|}
\hline Treatment & \multicolumn{2}{|c|}{ Dubas bug development stage } \\
\hline Density /cage & First instar & Third Instar \\
\hline Control & $0.00 \pm 00.00 \mathrm{f}$ & $0.00 \pm 0.00 \mathrm{f}$ \\
\hline $\mathbf{1 0}$ bugs & $1.45 \pm 0.14 \mathrm{e}$ & $0.75 \pm 0.11 \mathrm{f}$ \\
\hline $\mathbf{5 0}$ bugs & $7.50 \pm 0.27 \mathrm{~d}$ & $3.95 \pm 0.21 \mathrm{e}$ \\
\hline $\mathbf{1 0 0}$ bugs & $15.45 \pm 0.21 \mathrm{c}$ & $8.10 \pm 0.35 \mathrm{~d}$ \\
\hline $\mathbf{2 0 0}$ bugs & $22.00 \pm 1.14 \mathrm{~b}$ & $12.05 \pm 0.57 \mathrm{c}$ \\
\hline $\mathbf{4 0 0}$ bugs & $27.55 \pm 0.62 \mathrm{a}$ & $16.70 \pm 0.90 \mathrm{~b}$ \\
\hline 600 bug & $29.40 \pm 0.43 \mathrm{a}$ & $19.00 \pm 0.86 \mathrm{a}$ \\
\hline F-value & $\mathbf{1 6 2 . 9 8}^{*}$ & $\mathbf{1 2 1 . 1 9} *$ \\
\hline
\end{tabular}

*Means followed by different letters in the same column are significantly different at $\mathrm{P}<0.001$; Tukey's Range $=4.31$ )

Table 2. Mean number $( \pm \mathrm{SE}$ ) of first and third instar nymphs of $O$. lybicus, consumed (in 24 hours) by fourth instar $C$. septempunctata at different prey densities (average of four seasons: spring and summer, 2009-10)

\begin{tabular}{|c|c|c|}
\hline Treatment & \multicolumn{2}{|c|}{ Dubas bug development stage } \\
\hline Density/cage & First instar & Third Instar \\
\hline Control & $0.00 \pm 0.00 \mathrm{e}$ & $0.00 \pm 0.00 \mathrm{f}$ \\
\hline $\mathbf{1 0}$ bugs & $1.00 \pm 0.07 \mathrm{e}$ & $0.60 \pm 0.20 \mathrm{f}$ \\
\hline $\mathbf{5 0}$ bugs & $5.70 \pm 0.16 \mathrm{~d}$ & $3.35 \pm 0.29 \mathrm{e}$ \\
\hline $\mathbf{1 0 0}$ bugs & $12.60 \pm 0.37 \mathrm{c}$ & $6.00 \pm 0.37 \mathrm{~d}$ \\
\hline $\mathbf{2 0 0}$ bugs & $19.75 \pm 0.63 \mathrm{~b}$ & $11.35 \pm 0.32 \mathrm{c}$ \\
\hline $\mathbf{4 0 0}$ bugs & $26.25 \pm 0.64 \mathrm{a}$ & $16.15 \pm 0.40 \mathrm{~b}$ \\
\hline $\mathbf{6 0 0}$ bug & $28.80 \pm 0.85 \mathrm{a}$ & $18.25 \pm 0.32 \mathrm{a}$ \\
\hline F-value & $\mathbf{2 0 5 . 8 2} *$ & $\mathbf{1 2 1 . 9 3} *$ \\
\hline
\end{tabular}

*Means followed by different letters in the same column are significantly different at $\mathrm{P}<0.001$; d.f. $=$ 5, 29; Tukey's Range $=4.31$ ) 
Comparative consumption rate of fourth instar and adult female $C$. septempunctata

Significant difference was observed in the predation rate of adult female and fourth instar larva of $C$. septempunctata feeding on the same density and prey stage with same environmental conditions. Irrespective of prey density, mean predation per 24 hours of adult and grub stages of $C$. septempunctata was recorded as 13.66 and 12.48 prey, respectively (Fig. $3)$.

\section{Functional response}

Parameter estimated for logistic regression of proportion of prey killed $(\mathrm{Ne} / \mathrm{No})$ against the number of prey offered (No) for the adult female and $4^{\text {th }}$ instar grub of $C$. septempunctata feeding on first and $3^{\text {rd }}$ instar nymphs of dubas bug displayed type II functional response, i.e. significant linear parameter $\mathrm{P}_{1}<0$ (table 3 and fig. 1 and 2).

Figure 1 and 2 illustrated that functional response curves and predation percentage of both developmental stages of $C$. septempunctata was significantly high feeding on $1^{\text {st }}$ than $3^{\text {rd }}$ instar nymphs of dubas bug. Similarly, irrespective of prey stage the overall functional response curve of adult was higher than the grub, whereas at higher prey density the prey consumed by both developmental stages was at par (fig. 3). Two- way ANOVA revealed a significant main effect of "prey stage" $(\mathrm{F}=$ 314.79; $\mathrm{P}<0.0001 ;$ d.f. $=1$ ) and "prey density" $(\mathrm{F}=278.93 ; \mathrm{P}<0.0001 ;$ d.f. $=5)$ when adult female $C$. septempunctata was searching. The interaction between "prey stage" and "prey density" was also found to be significant $(\mathrm{F}=20.87 ; \mathrm{P}<0.001$; d.f. $=$ 5). Similarly, main effect of "prey stage" $(\mathrm{F}=584.64 ; \mathrm{P}<0.0001 ;$ d.f. $=1)$ and "prey density" $(\mathrm{F}=321.23 ; \mathrm{P}<0.0001 ;$ d.f. $=5)$ was also significant when fourth instar $C$. septempunctata was searching. The interaction between "prey stage" and "prey density" was also found to be significant $(\mathrm{F}=37.71 ; \mathrm{P}<0.001 ;$ d.f. $=5)$.
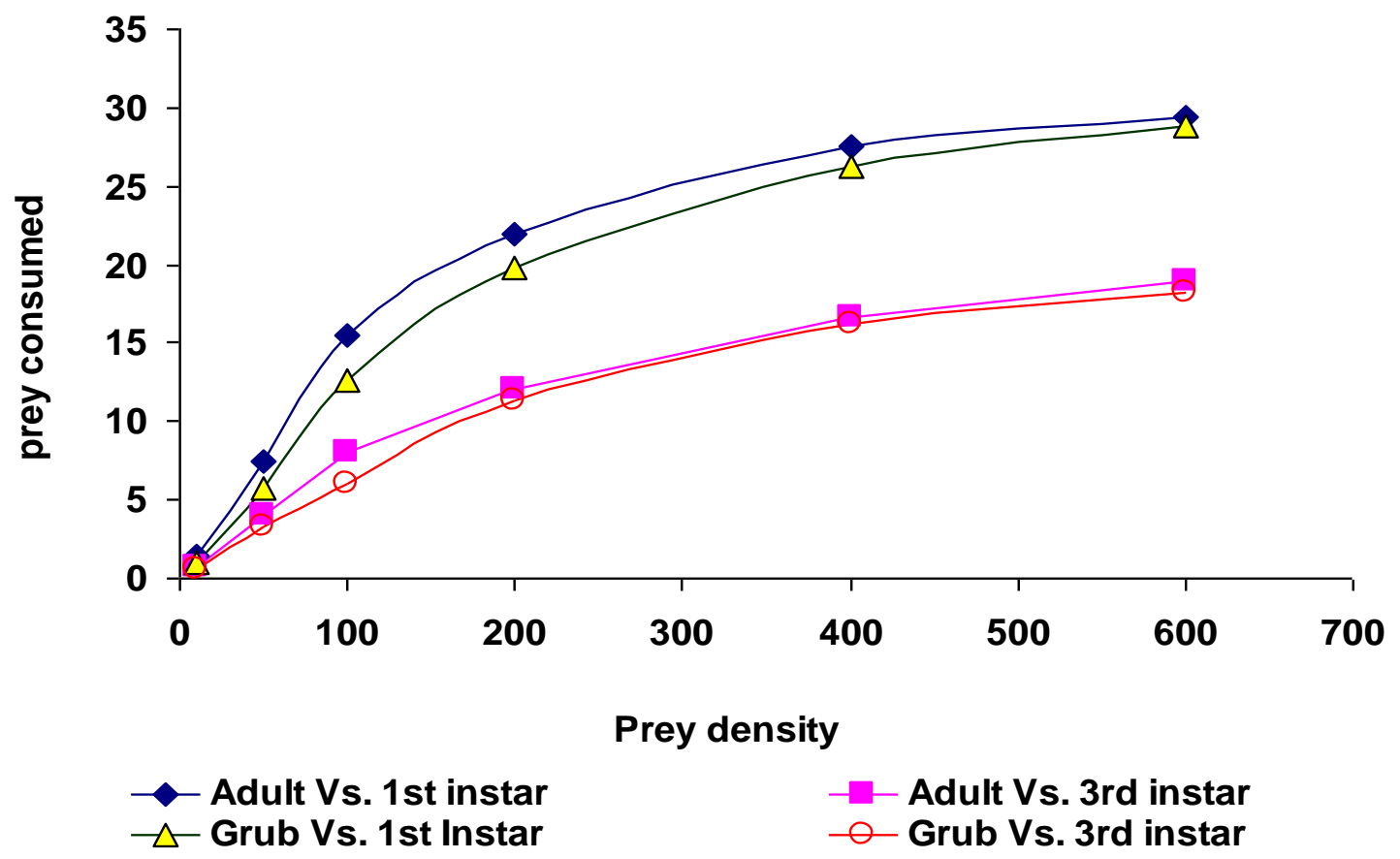

Adult Vs. 3rd instar Grub Vs. 3rd instar

Figure 1. Functional response of adult female and fourth instar $C$. septempunctata (obtained from the predicted values of prey consumed by PROC-NLIN procedure of SAS), preying upon $1^{\text {st }}$ and $3^{\text {rd }}$ instar nymphs of dubas bug offered at different density levels (average of four seasons, 2009-10) 

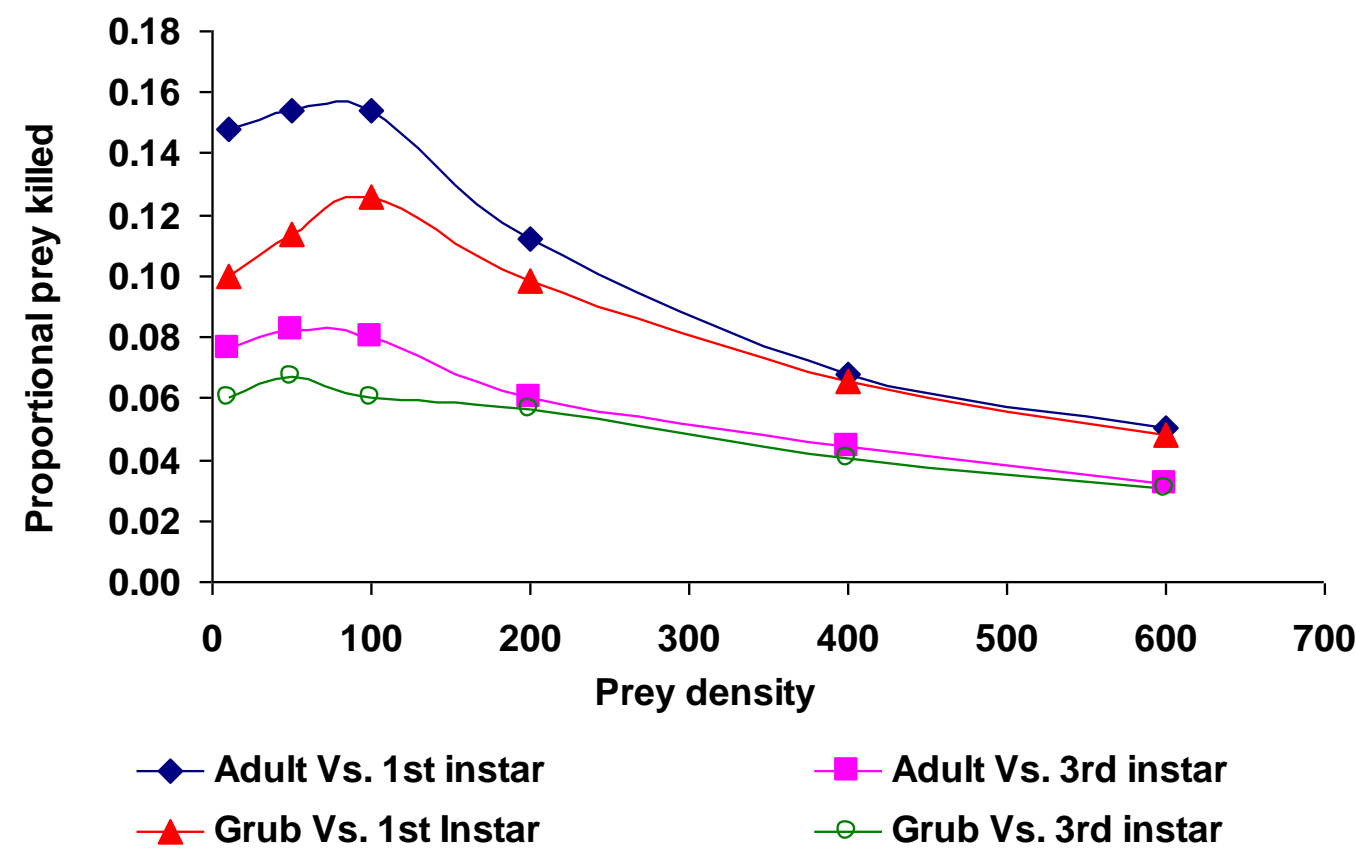

Figure 2. Functional response of $C$. septempunctata adult and grub preying upon $1^{\text {st }}$ and $3^{\text {rd }}$ instar nymphs of dubas bug offered at different density levels (average of four seasons, 2009-10)

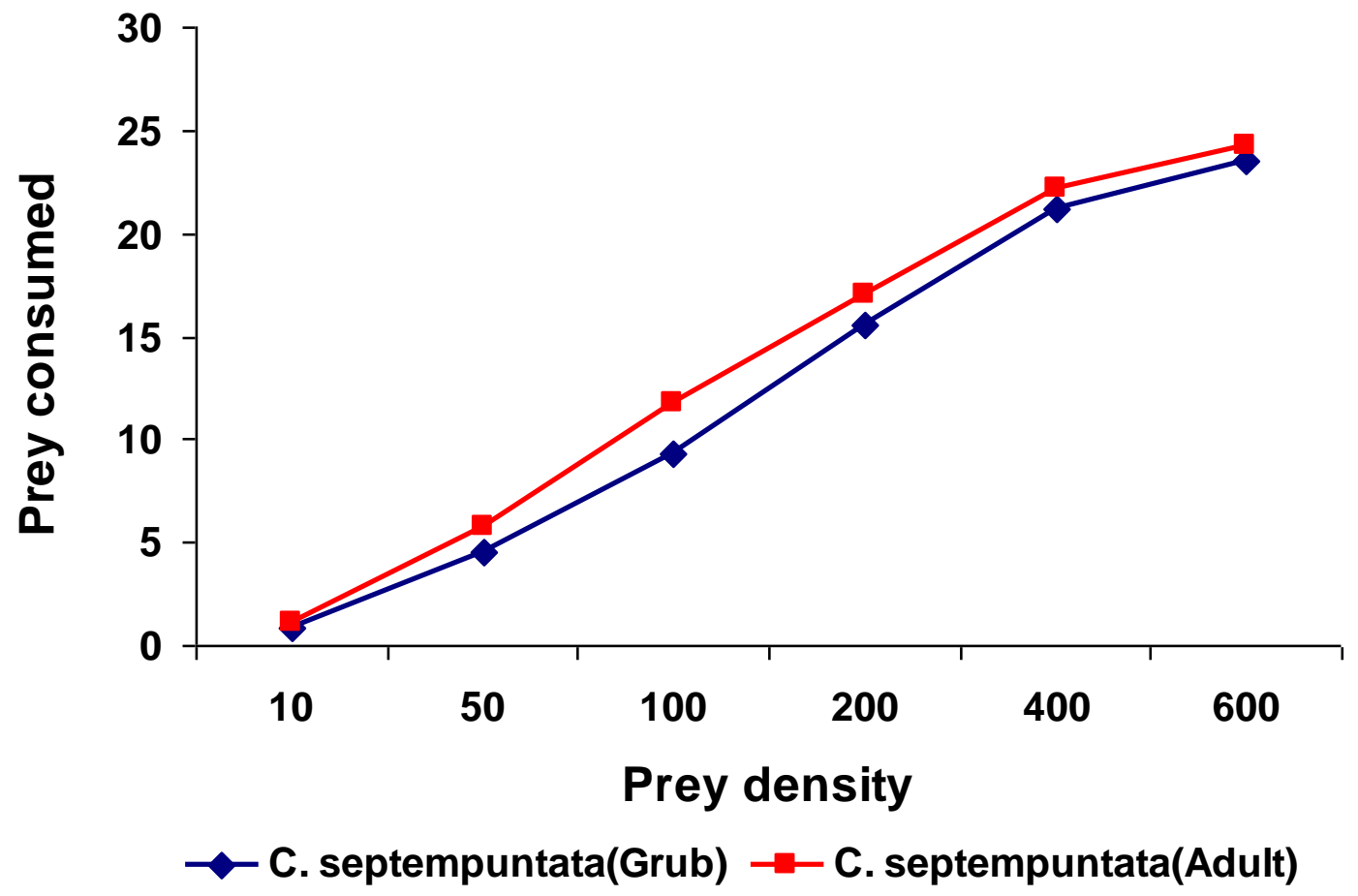

Figure 3. Comparative functional response of $C$. septempunctata adult and grub at different densities of dubas bug (irrespective of life stages)

Handling time and search rate

Prey stage significantly affected the handling time and it increased with increasing prey size. Adult female $C$. septempunctata spent shortest time, followed by fourth instar feeding on $1^{\text {st }}$ instar nymphs of dubas bug. Similarly search rate of predator decreased when 
prey stage developed. Regardless of prey stage overall search rate of fourth instar $C$. septempunctata was shorter than adult (table 4).

Table 3. Functional response model based on analysis of maximum likelihood estimates of parameters $( \pm \mathrm{SE})$ using proportional prey killed as function of initial prey densities by $C$. septempunctata (average of four seasons: spring and summer 2009-10)

\begin{tabular}{|c|c|c|c|c|c|c|}
\hline $\begin{array}{l}\text { Predator } \\
\text { stage }\end{array}$ & $\begin{array}{c}\text { Prey } \\
\text { stage }\end{array}$ & $\begin{array}{c}\text { Intercept } \\
\left(\mathbf{P}_{\mathbf{0}}\right)\end{array}$ & $\begin{array}{c}\text { Linear } \\
\left(\mathbf{P}_{\mathbf{1}}\right)\end{array}$ & $\begin{array}{c}\text { Quadratic } \\
\left(\mathbf{P}_{\mathbf{2}}\right)\end{array}$ & $\begin{array}{c}\text { Cubic } \\
\left(\mathbf{P}_{\mathbf{3}}\right)\end{array}$ & $\begin{array}{c}\text { Best Fitted } \\
\text { model }\end{array}$ \\
\hline \multirow{3}{*}{$\begin{array}{c}\text { Adult } \\
\text { Female }\end{array}$} & $1^{\text {st }}$ Instar & -1.655 & -0.004 & -0.000081 & 0.000000096 & \\
\cline { 2 - 7 } & & -2.529 & -0.004 & 0.000062 & 0.000000046 & \\
& $3^{\text {rd }}$ Instar & \pm 0.33 & \pm 0.003 & \pm 0.000001 & \pm 0.000000002 & Type II \\
\hline Fourth & & -1.868 & -0.004 & -0.000025 & 0.000000023 & \\
Instar & $1^{\text {st }}$ Instar & \pm 0.263 & \pm 0.004 & \pm 0.000001 & \pm 0.000000001 & Type II \\
\cline { 2 - 7 } & & -3.037 & -0.002 & 0.000045 & 0.000000014 & \\
& \multirow{2}{*}{$3^{\text {rd }}$ Instar } & \pm 0.413 & \pm 0.005 & \pm 0.00001 & \pm 0.000000001 & Type II \\
\hline
\end{tabular}

Table 4. Estimated attack rate (a') and handling time $\left(\mathbf{T}_{h}\right)$ of $C$. septempunctata on two life stages and seven densities of dubas bug, $O$. lybicus (average of four seasons; spring and summer 2009-10)

\begin{tabular}{|c|c|c|c|c|c|c|}
\hline $\begin{array}{l}\text { Predator } \\
\text { Stage }\end{array}$ & $\begin{array}{l}\text { Dubas } \\
\text { stage }\end{array}$ & Parameter & Estimated & SE & t value & $\operatorname{Pr}(>|\mathbf{t}|)$ \\
\hline \multirow{6}{*}{$\begin{array}{l}\text { (Adult } \\
\text { female) }\end{array}$} & \multirow{2}{*}{$1^{\text {st }}$ Instar } & $a^{\prime}$ & 0.02 & 0.002 & 8.621 & 0.00 \\
\hline & & Th & 0.563 & 0.024 & 23.020 & 0.00 \\
\hline & \multirow{2}{*}{$3^{\text {rd }}$ Instar } & $\mathrm{a}^{\prime}$ & 0.003 & 0.0001 & 8.050 & 0.00 \\
\hline & & $\mathrm{Th}$ & 1.008 & 0.121 & 8.300 & 0.00 \\
\hline & \multirow{2}{*}{ Average } & $\mathrm{a}^{\prime}$ & 0.011 & 0.001 & 8.335 & 0.00 \\
\hline & & Th & 0.785 & 0.027 & 15.66 & 0.00 \\
\hline \multirow{6}{*}{$\begin{array}{c}\text { (4h instar } \\
\text { grub) }\end{array}$} & \multirow{2}{*}{$1^{\text {st }}$ Instar } & $a^{\prime}$ & 0.014 & 0.001 & 9.917 & 0.00 \\
\hline & & $\mathrm{Th}$ & 0.692 & 0.029 & 23.840 & 0.00 \\
\hline & \multirow{2}{*}{$3^{\text {rd }}$ Instar } & $\mathrm{a}^{\prime}$ & 0.002 & 0.0001 & 6.563 & 0.00 \\
\hline & & Th & 1.492 & 0.227 & 6.571 & 0.00 \\
\hline & \multirow{2}{*}{ Average } & $\mathrm{a}^{\prime}$ & 0.008 & 0.0001 & 8.240 & 0.00 \\
\hline & & $\mathrm{Th}$ & 1.092 & 0.128 & 15.205 & 0.00 \\
\hline
\end{tabular}

$\mathrm{a}^{\prime}\left(\mathrm{cm}^{2} /\right.$ hour), $\mathrm{T}_{\mathrm{h}}$ (days or hours/prey), Predation time for predators was 24 hours

\section{Discussion}

Developmental stage of dubas bug significantly influenced the consumption rate of both stages of $C$. septempunctata. This may be due to difference in body size and mobility of and $3^{\text {rd }}$ instar nymphs of dubas bug. Similar results were indicated by [20], who found that prey size and hunger level of predators affected the predation ratio. Density level of prey significantly affected the predation rate of $4^{\text {th }}$ instar grub and adult of C. septempunctata. Predation rate increased with increasing prey density, while percentage of predation was inversely proportional to prey density level. The more predation at higher density could be due to more chance for predator for searching and killing of prey than lower prey density. Generally these investigations are in line with [21-23]. At high prey density predation frequency of ladybirds decrease with predation time however, it was not observed at low prey 
density [22]. C. septempunctata consumed more than $50 \%$ of prey during the first three hours exposed for 24 hours [24]. In other study, [25] reported that $4^{\text {th }}$ instar grub of seven spotted beetle consumed 2.8 and 2.55 aphids (Lipaphis erysimi Kalt.) under laboratory and field conditions offered at density level of 10 aphids, respectively. It is assumed that this difference may be on account of difference in prey species, experimental arena, prevailing environmental condition during experiment and difference in geographical provenance of $C$. septempunctata species.

Adult $C$. septempunctata consumed significantly more dubas bug than $4^{\text {th }}$ instar grub when offered at the same density, stage and under the same environmental condition. This was probably due to comparatively poor visual perception of $4^{\text {th }}$ instar larvae of $C$. septempunctata than adult, which detect the prey at distance of about $1.0 \mathrm{~cm}$ and $0.7 \mathrm{~cm}$, respectively [26]. Coccinella septempunctata finds the first prey (patch) only under light conditions (at a distance of $7 \mathrm{~mm}$ ) and upon coming in contact under dark conditions [27]. Generally, present results are in consonance with the findings of [28] who found that larvae of C. septempunctata spent longer time in finding a prey and adapted to search for aggregated prey. Our findings is in close agreement with those of [29], who claimed that adult $C$. septempunctata had a lesser prey handling time with high attack rate than the fourth instars. Food consumption of $C$. septempuctata grub increased with development of instars [30], while, [21] reported that $C$. septempunctata grub feeding rate was two fold greater than those of adult feeding on aphid species. This variation may be due to feeding behavior /preference of predator which may change under different environmental variables [31].

Present study showed that both developmental stages of $C$. septempunctata, illustrated type II functional response feeding on $1^{\text {st }}$ and $3^{\text {rd }}$ instar nymphs of dubas bug. Predators displayed such type of functional response consumed higher number of prey with high prey availability, but the rate of predation/consumption decreased with increasing prey density and plateau in functional response curve indicated predator saturation. Similar type of response (FR II) has been reported for $C$. septempunctata preyed on: Lipaphis erysimi (Kaltenbach) [32], green apple aphid Aphis pomi De Geer [33], Aphis glycines [34].

Predators demonstrate similar functional response curve cannot be deemed to respond in the same way in term of handling time and search rate [12]. Present results showed that handling time of both stages of $C$. septempunctata varied significantly and it increased with prey (dubas) developmental stage, which indicates that predator have different abilities to response against different prey stage/size. Being the first study no reference is available to compare the result of present study with earlier work. However, generally these results are in line with [35] who found that handling time includes time it takes to: chase, kill, subdue and eat/digest a prey item, once the prey is located. While this study disagree with [36] who reported that handling time of Exochomus nigromaculatus decrease with developmental stage of $H$. pruni. This discrepancy may be due to dissimilarity in prey and predator: species, size, development stage, degree of predator hunger and most importantly some environmental variables.

Search rate (a) and handling time (Th) of both stages of $C$. septempunctata was significantly high preying on $1^{\text {st }}$ instar nymphs of dubas bug compared to 3rd instar nymphs; indicated comparatively more mobility of $3^{\text {rd }}$ instar than $1^{\text {st }}$ instar dubas bug. Other possibly reasons may be due to variation in prey distribution [28], effect of temperature on predation and search rate of predator $[37,38]$. While higher handling time of both stages on $3^{\text {rd }}$ 
instar nymphs showed that both stages of predator need more time to grasp $3^{\text {rd }}$ instar than $1^{\text {st }}$ instar.

In comparison, adult had significantly shorter handling time and higher search rate compared to grub, they take less time to process the food and take comparatively more time to locate the prey (may be due to mobility), which showed that $C$. septempunctata adult is more efficient in terms of food processing.

Based on present result of consumption rate, functional response, handling time and attack rate between two stages of predator that varied significantly we can conclude that though both development stages of $C$. septempunctata illustrated type II functional response but adult is the most efficient than grub. Functional response of predators can be affected by different biotic and a-biotic factors. However, field studies on predator and prey stage, sex specific, temperature and host plant in the presence of honeydew droplets on leaflets are still needed to quantify biocontrol efficiency of predator.

\section{Authors' contributions}

Conceived and designed the experiments: A Shah, MQ Kakar \& T Iqbal, Performed the experiments: A Shah \& H Ullah, Analyzed the data: NE Papanikolaou \& A Shah, Contributed reagents/ materials/ analysis tools: A Shah, A Ullah \& A Razaq, Wrote the paper: A Shah.

\section{Acknowledgement}

This study was completed with the Financial Assistance of Pakistan Science Foundation, Islamabad under the Project No. PSF/Res/B-ACD/Agr (379).

\section{References}

1. Mokhtar AM, \& Al-Nabhani SS (2010). Temperature-dependent development of dubas bug, Ommatissus lybicus (Hemiptera: Tropiduchidae), an endemic pest of date palm, Phoenix dactylifera. Eur $J$ Entomol 107: 681-685.

2. El-Haidri HS \& AL-Hafidh EMT (1986). Palm and date arthropods pests in the Near-East and North Africa, (in
Arabic). Project for palm and date Research Centre in the near east and North Africa. FAO Bulletin, Baghda. $126 \mathrm{p}$

3. Gharib A (1966). Ommatissus binotatus Fieb.Var. lybicus Berg. App Entomo and Phytopatho 24: 37-47.

4. Hussain AA (1963). Biology and control of dubas bug Ommatissus binotatus var. lybicus de-Berg. (Homoptera: Tropiduchida) infesting date palm in Iraq. Bull Entomol Res 53: 737-745.

5. Klein M \& Venezian A (1985). The dubas date Tropiduchid, Ommatissus binotatus lybicus, a threat to date palm in Israel. Phytoparastica 13: 95-101.

6. GOB (2006). Project proposal for the control of dubas bug in Panjgur district. Agric. Extension Dept. Balochistan Report.

7. Hussain AA (1974). Dates palm and Dates with their pests in Iraq. University of Baghdad Ministry of Higher Education and Scientific Research Iraq. 166 pp.

8. Kranz J, Schmutterer H \& Koch W (1978). Diseases, pests, and weeds in tropical crops. Soil Sci 125: 272.

9. Işıkber AA \& Copland MJW (2003). Effects of various aphid foods on Cycloneda sanguinea. Entomol Exp Appl 102: 93-97.

10. Obrycki JJ \& Kring TT (1998). Predaceous Coccinellidae in biological control. Ann Rev Entomol 43: 295-321.

11. Oliveira EE, Oliveira CL, Sarmento RA, Rezende LM \& Fadini MAM (2004). Aspectos biológicos do predador Cycloneda sanguinea (Coleoptera: Coccinellidae) alimentado com Tetranychus evansi (Acari: Tetranychidae) Macrosiphum euphorbiae (Homoptera: Aphididae). Biosci J 21: 33-39.

12. Pervez A \& Omkar (2005). Functional responses of coccinellid predators: An illustration of a logistic approach. $J$ Insect Sci 5: 1-6. 
13. Murdoch WW \& Oaten A (1975). Predation and population stability. $A d v$ Ecol Res 9: 1-131.

14. Holling CS (1959). Some characteristics of simple type of predation and parasitism. Can Entomol 91: 385-398.

15. Holling CS (1965). The functional response of predators to prey density and its role in mimicry and population regulation. Mem Entomol Soc Can 45: 3-60.

16. Parajulee MN, Shrestha RB, Leser JF, Wester DB \& Blanco CA (2006). Evaluation of the functional response of selected arthropod predators on bollworm eggs in the laboratory and effect of temperature on their predation efficiency. Environ Entomol 35: 379386.

17. Trexler JC, Charles EM \& Travis J (1988). How can the functional response best be determined? Oecologia. 76: 206-214.

18. Bassim HA (2003). Biological performance of dubas bug Ommatissus lybicus De Berg. (Homoptera: Tropiduchidae) under field conditions and predicting of its appearance by using degree-day model. M.Sc. Thesis. Department of Plant Protection, College of Agriculture, University of Baghdad, Abu Ghraib, Baghdad, Iraq.

19. Juliano SA (2001). Nonlinear curve fitting: Predation and Functional response curve. In: S.M. Scheiner and J. Gurevitch (eds.) "Design and Analysis of Ecological Experiments, Second Edition". Oxford University Press. p. 178-196.

20. Frazer BD \& McGregor RR (1992). Temperature-dependent survival and hatching rate of eggs of seven species of Coccinellidae. Can Entomol 124: 305-312.

21. Inayat TP, Rana SA, Rana N, Ruby T, Sadiqui MJI \& Abbas MN (2011). Predation Rate in Selected Coccinellid (Coleoptera) Predators on some Major
Aphidid and Cicadellid (Hemipteran) Pests. Int J Agric Bio 13: 427-430.

22. Yasuda H \& Ishikawa H (1999). Effects of prey density and spatial distribution on prey consumption of the adult predatory ladybird beetle. $J$ Appl Entomol 123: 585-589.

23. Rai S, Singh NN \& Shankar U (2010). Functional response of grub and adult of Coccinella septempunctata (L.) and Coccinella transversalis (Fabr.) on mustard aphid, Lipaphis erysimi (Kalt.). Arch Phytopathol 43: 18291835.

24. Shukla AN, Singh R \& Tripathi CPM (1990). Effect of Predation Period on the Functional Fesponse of Coccinella septempunctata L. (Coleoptera, Coccinellidae), a predator of Lipaphis erysimi Kalt (Hemiptera, Aphididae). $J$ Advance Zool 11: 27-32.

25. Solangi BK, Lohar MK, Abro GH \& Talpur MA (2007). Searching ability and feeding potential of larvae, 7spotted beetle Coccinella septempunctata Linn. Under laboratory and field conditions. Sarhad J Agric 23: 705-711.

26. Stubbs M (1980). Another look at prey detection by Coccinellids. Ecological Entomol 5: 179-182.

27. Nakamuta K (1984). Visual orientation of a ladybeetle, Coccinella septempunctata L. (Coleoptera: Coccinellidae), towards its prey. App Entomol Zool 19: 82-86.

28. Murakami Y \& Tsubaki Y (1984). Searching efficiency of the lady beetle Coccinella septempunctata larvae in uniform and patchy environments. $J$ Ethology 2: 1-6.

29. Gupta RK, Pervez A, Guroo MA, \& Srivastava K (2012). Stage-specific functional response of an aphidophagous ladybird, Coccinella septempunctata (Coleoptera: Coccinellidae), to two aphid species. Int J Trop Insect Sci 32: 136-141.

30. Sattar M, Hamed $M$ \& Nadeem $S$ (2008). Biology of Coccinella 
septempunctata Linn. (Coleoptera: Coccinellidae) and its predatory potential on cotton aphids, Aphis gossypii glover (Hemiptera: Aphididae). Pak J Zool 40: 239-242.

31. Khan MR \& Khan MR (2010). The relationship between temperature and functional response of Coccinella septempunctata $(\mathrm{L}) \quad$ (Coleoptera: Coccinellidae). Pak J Zool 42: 461466.

32. Omkar \& Srivastava S (2003). Functional Response of the Seven spotted Lady Beetle, Coccinella Septempunctata Linnaeus on the Mustard Aphid, Lipaphis Erysimi (Kaltenbach). Intl J Trop Insect Sci 23: 149-152.

33. Khan AA \& Mir RA (2008). Functional response of four predaceous coccinellids, Adalia tetraspilota (Hope), Coccinella septempunctata L., Calvia punctata (Mulsant) and Hippodamia variegata (Goeze) feeding on the green apple aphid, Aphis pomi De Geer (Homoptera: Aphididae). J Biolog Control 22: 291-298.

34. Xue Y, Bahlai CA, Frewin A, Sears MK, Schaafsma AW \& Hallett RH
(2009). Predation by Coccinella septempunctata and Harmonia axyridis (Coleoptera: Coccinellidae) on Aphis glycines (Homoptera: Aphididae). Environ Entomol 38: 708-714.

35. Veeravel R \& Baskaran P (1997). Functional and Numerical Responses of Coccinella transversalis Fab. and Cheilomenes sexmaculatus Fab. Feeding on the Melon Aphid, Aphis gossypii Glov. Int J Trop Insect Sci 17: 335-339.

36. Atlıhan R \& Özgökçe MS (2002). Development, fecundity and prey consumption of Exochomus nigromaculatus feeding on Hyalopterus pruni Phytoparasitic 30: 443-450.

37. Menon S, Hansen JE, Nazarenko L \& Luo Y (2002). Climate effects of black carbon aerosols in China and India. Science 297: 2250-2253.

38. Xia JY, Rabbinge R, \& Van Der Werf, W (2003). Multistage functional responses in a ladybeetle-aphid system: scaling up from the laboratory to the field. Environ Entomol 32(1):151-162. 